\title{
Phototransformation of Air Pollutants: Rapid Test for the Determination of $k_{\mathrm{OH}}$
}

\author{
W. Klöpffer, G. Kaufmann, and R. Frank \\ Battelle-Institut e.V., Abteilung Chemie und Ökologie, Frankfurt (Main) \\ Dedicated to Professor Schulte-Frohlinde on the occasion of his 60th anniversary
}

Z. Naturforsch. 40a, 686-692 (1985); received April 15, 1985

\begin{abstract}
An empirical correlation between the $k_{\mathrm{OH}}$ rate constants in air and in water is derived from literature values. A simple method to measure $k_{\mathrm{OH}}$ in water has been used. In addition, it is demonstrated that the reactivity of organic chemicals with the $\mathrm{OH}$ radical in Freon 113 is proportional to their reactivity in air.
\end{abstract}

\section{Introduction}

The reaction with the $\mathrm{OH}$ radical is the major sink for most air pollutants in the troposphere. The rate constant $k_{\mathrm{OH}}$ of this reaction is measured in smog chambers or by various flash photolysis methods [1]. One limiting factor in these measurements is the vapour pressure of the substances which should be greater than approximately $10^{-2} \mathrm{~Pa}$; however, substances with vapour pressures down to about $10^{-6} \mathrm{~Pa}$ have been reported to occur in the trophosphere in molecular form [2, 3]. It therefore would be desirable to have a method for measuring or at least estimating $k_{\mathrm{OH}}$ for these compounds. Furthermore, chemical legislation demands an estimate of abiotic degradation, including data on the lifetime of chemicals in the troposphere. Clearly, for an estimate of a chemical's tropospheric liefetime, $k_{\mathrm{OH}}$ and the concentration of the $\mathrm{OH}$ radical in the troposphere have to be known. A rapid and comparatively inexpensiv test method is therefore wanted in order to determine $k_{\mathrm{OH}}$ during initial testing of "new substances" and screening of large numbers of "old substances".

In this paper, a suitable rapid test for watersoluble substances is described, which is based on the work by Walling [4]. The measurement is performed in aqueous, acidic solution and thus is primarily relevant to the phototransformation in water (e.g. in clouds). In order to estimate the gasphase data of $k_{\mathrm{OH}}$, a correlation with $k_{\mathrm{OH}}$ data valid for the aqueous phase has to be used [5].

Reprint requests to Prof. Dr. W. Klöpffer, Battelle-Institut e.V., Abt. Chemie und Ökologie, Am Römerhof 35, 6000 Frankfurt a. M. 90.
The method is not suitable for water-insoluble substances. For such substances we have explored a different technique. The method uses F 113 as an inert solvent and $\mathrm{H}_{2} \mathrm{O}_{2}$ as a source of photochemically generated $\mathrm{OH}$ radicals. First results also reported in this paper.

\section{Methods}

\subsection{Correlation Between $k_{\mathrm{OH}}$ Measured in Water and in the Gasphase}

The rapid test described in this paper is based on the determination of $k_{\mathrm{OH}}$ in an inert solvent. Using a correlation between the rate constants in the liquid phase $k_{\mathrm{OH}}$ (liquid) and in the gas phase $k_{\mathrm{OH}}$ (air), the unknown rate constant of a substance in the gas phase can be estimated if the rate constant is measured in the same solvent [5]. Güsten et al. [6] found the following correlation for water as solvent:

$$
\log k_{\mathrm{OH}} \text { (air) }=-21.9+1.14 \log k_{\mathrm{OH}} \text { (water), }
$$

where $k_{\mathrm{OH}}$ (water) is in $\mathrm{M}^{-1} \mathrm{~s}^{-1}$ and $k_{\mathrm{OH}}$ (air) in $\mathrm{cm}^{3} \mathrm{~mol}^{-1} \mathrm{~s}^{-1}$. The different units are due to the use of the most frequent units for liquid solution and gas phase measurements, respectively, in [6].

Using more data, Klöpffer et al. [7, 8] found

$$
\log k_{\mathrm{OH}}\left(\text { air) }=1.29+0.891 \log k_{\mathrm{OH}}\right. \text { (water), }
$$

where both rate constants are given in the "liquid phase unit" $\mathrm{M}^{-1} \mathrm{~s}^{-1}$. The data are compiled in Table 1 and presented graphically in Figure 1. The correlation appears to be invalid only for very small molecules and for aromatics with electron-withdrawing substituents. It will be used for estimating gas phase data from $k_{\mathrm{OH}}$ (water) in Section 3.

0340-4811/85/0700-0686\$01.30/0. - Please order a reprint rather than making your own copy. 
Table 1. Decadic logarithms of recommended $k_{\mathrm{OH}}$ rate constants $\left(\mathrm{M}^{-1} \mathrm{~s}^{-1}\right)$.

\begin{tabular}{|c|c|c|c|c|}
\hline Substance & $\begin{array}{c}\log k_{\mathrm{OH}} \\
\text { (water) }\end{array}$ & Ref. & $\begin{array}{l}\log k_{\mathrm{OH}} \\
\text { (air) }\end{array}$ & Ref. \\
\hline i-Propanol & 9.3 & [9] & 9.6 & {$[1,15]$} \\
\hline Aniline & 10.23 & [10] & 10.85 & \\
\hline Formaldehyde & 9.1 & [9] & 9.89 & [1] \\
\hline Anisol & 10.08 & [9] & 10.07 & {$[15]$} \\
\hline o-Xylene & 9.83 & {$[11,12]$} & 9.95 & {$[15]$} \\
\hline m-Xylene & 9.88 & {$[11,12]$} & 10.16 & {$[15]$} \\
\hline p-Xylene & 9.85 & {$[11,12]$} & 9.92 & {$[1,15]$} \\
\hline Mesitylene & 9.81 & [12] & 10.57 & [15] \\
\hline Phenol & 10.2 & {$[9,11]$} & 10.22 & [1] \\
\hline Methylamine & 9.84 & [10] & 10.12 & [15] \\
\hline Ethylene & 9.45 & {$[9,11]$} & 9.70 & {$[1,15]$} \\
\hline Dimethyl sulphide & 9.72 & [9] & 10.4 & {$[1,15]$} \\
\hline Acetonitrile & 6.54 & [9] & 7.18 & [1] \\
\hline Biacetyl & 8.23 & {$[13,9]$} & 8.16 & [15] \\
\hline Ethyleneoxide & 7.59 & [14] & 7.78 & [1] \\
\hline Acrylonitrile & 9.53 & [9] & 9.38 & [1] \\
\hline t-Butanol & 8.7 & [11] & 8.8 & {$[15]$} \\
\hline Naphtalene & 10.07 & [11] & 10.06 & [1] \\
\hline Diphenyl & 9.87 & [11] & 9.66 & [1] \\
\hline Carbon disulphide & 9.91 & [11] & 9.12 & [1] \\
\hline Benzonitrile & 9.7 & [11] & 8.3 & [1] \\
\hline Chlorobenzene & 9.65 & [11] & 9.81 & [1] \\
\hline Nitrobenzene & 9.5 & [11] & 7.95 & [1] \\
\hline o-Nitrophenol & 9.96 & [11] & 8.75 & [1] \\
\hline Benzene & 9.89 & [9] & 8.84 & {$[1,15]$} \\
\hline Chloroform & 6.93 & [14] & 8.1 & {$[1,15]$} \\
\hline p-Cresol & 10.08 & [14] & 10.5 & [15] \\
\hline Ethanol & 9.26 & [9] & 9.3 & {$[1,15]$} \\
\hline Ethyl acetate & 8.38 & [14] & 9.06 & [15] \\
\hline Methanol & 8.95 & {$[9,11]$} & 8.82 & {$[1,15]$} \\
\hline Propanol & 9.45 & {$[9,11]$} & 9.55 & {$[1,15]$} \\
\hline n-Propyl acetate & 9.15 & [9] & 9.41 & [15] \\
\hline Toluene & 9.48 & [9] & 9.57 & {$[1,15]$} \\
\hline Methyl ethyl ketone & 8.95 & [9] & 9.32 & {$[15]$} \\
\hline Tetrahydrofuran & 9.43 & [9] & 9.95 & {$[15]$} \\
\hline Methyl acetate & 8.08 & [9] & 8.04 & {$[15]$} \\
\hline Methyl propionate & 8.65 & [9] & 8.23 & [15] \\
\hline Ethyl propionate & 8.94 & [9] & 9.03 & [15] \\
\hline 1,2-Epoxybutane & 8.65 & [14] & 8.89 & [15] \\
\hline Epoxypropane & 8.15 & [14] & 8.89 & {$[15]$} \\
\hline Diethyl ether & 9.37 & [14] & 9.73 & [15] \\
\hline Nitromethane & 8.28 & [14] & 8.81 & {$[15]$} \\
\hline Cyclohexane & 9.94 & [9] & 10.61 & {$[15]$} \\
\hline Acetone & 7.95 & {$[9,11]$} & 8.15 & [1] \\
\hline n-Butanol & 9.63 & {$[9,11]$} & 9.7 & {$[1,15]$} \\
\hline Allyl alcohol & 9.77 & [16] & 10.19 & [15] \\
\hline Benzaldehyde & 9.64 & [11] & 9.86 & {$[17]$} \\
\hline Cyclopentane & 9.48 & {$[11]$} & 9.5 & [18] \\
\hline Acrolein & 9.85 & [11] & 10.06 & {$[17]$} \\
\hline Thiophene & 9.52 & [11] & 9.76 & [1] \\
\hline Trichloroethylene & 9.48 & {$[11]$} & 9.2 & [1] \\
\hline Vinyl chloride & 9.85 & [11] & 9.6 & [1] \\
\hline Methyl mercaptan & 10.5 & [9] & 10.9 & [1] \\
\hline Butyraldehyd & 9.55 & [9] & 9.2 & {$[1]$} \\
\hline Methane & 8.08 & [11] & 6.69 & {$[1,19]$} \\
\hline Acetaldehyde & 8.7 & [11] & 9.94 & [1] \\
\hline Glycol & 9.3 & [11] & 9.68 & [1] \\
\hline 1-Butene & 9.89 & {$[11]$} & 10.33 & {$[1]$} \\
\hline 1,3-Butadiene & 9.89 & [11] & 10.61 & [1] \\
\hline Cyclohexene & 9.94 & {$[9,11]$} & 10.63 & [1] \\
\hline Propylene oxide & 8.38 & [11] & 8.5 & {$[15]$} \\
\hline
\end{tabular}

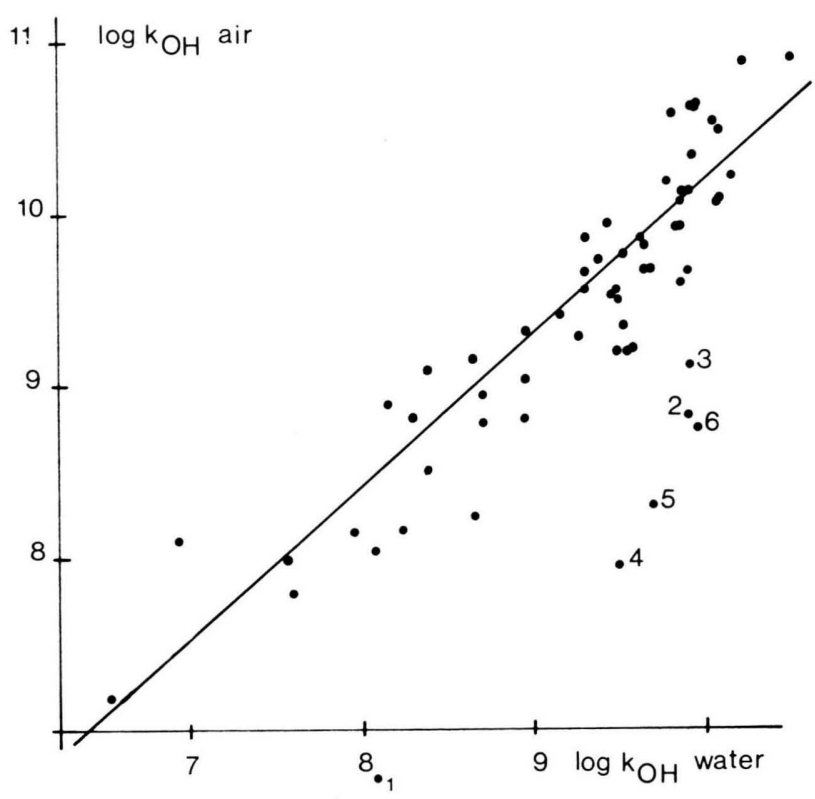

Fig. 1. Correlation between $k_{\mathrm{OH}}$ (water) and $k_{\mathrm{OH}}$ (air); 1 methane, 2 benzene, 3 carbon disulphide, 4 nitrobenzene, 5 benzonitrile, 6 o-nitrophenol.

\subsection{Determination of $k_{\mathrm{OH}}$ in Water}

\subsubsection{Measuring Principle and Evaluation}

The rate constant $k_{\mathrm{OH}}$ is determined according to Walling's method $[4,13]$ in which $\mathrm{OH}$ radicals are generated by the reaction of $\mathrm{H}_{2} \mathrm{O}_{2}$ with $\mathrm{Fe}$ (II). Walling proposed the following reaction scheme for the kinetic analysis:

$$
\begin{aligned}
& \mathrm{H}_{2} \mathrm{O}_{2}+\mathrm{Fe}^{++} \stackrel{k_{1}}{\rightarrow} \mathrm{Fe}^{+++}+\mathrm{OH}^{-}+\cdot \mathrm{OH} ; \begin{array}{l}
k_{1}=76 \\
\mathrm{M}^{-1} \mathrm{~s}^{-1},
\end{array} \\
& \cdot \mathrm{OH}+\mathrm{Fe}^{++} \stackrel{k_{2}}{\rightarrow} \mathrm{Fe}^{3+}+\mathrm{OH}^{-} ; \begin{array}{c}
k_{2}=3 \cdot 10^{8} \\
\mathrm{M}^{-1} \mathrm{~s}^{-1},
\end{array} \\
& \cdot \mathrm{OH}+\mathrm{R}_{1} \mathrm{H} \stackrel{k_{31}}{\rightarrow} \mathrm{H}_{2} \mathrm{O}+\mathrm{R}_{1}, \\
& \cdot \mathrm{OH}+\mathrm{R}_{2} \mathrm{H} \stackrel{k_{32}}{\rightarrow} \mathrm{H}_{2} \mathrm{O}+\mathrm{R}_{2}, \\
& \cdot \mathrm{OH}+\mathrm{R}_{3} \mathrm{H} \stackrel{k_{33}}{\rightarrow} \mathrm{H}_{2} \mathrm{O}+\mathrm{R}_{3}, \\
& \mathrm{R}_{1}+\mathrm{Fe}^{+++} \stackrel{k_{4}}{\rightarrow} \mathrm{Fe}^{++}+\mathrm{Prod}_{2}, \\
& 2 \mathrm{R}_{2} \stackrel{k_{5}}{\rightarrow} \mathrm{Dimer}, \\
& \mathrm{R}_{3}+\mathrm{Fe}^{++} \stackrel{k_{6}}{\rightarrow} \mathrm{Fe}^{+++}+\mathrm{R}_{3} \mathrm{H} .
\end{aligned}
$$


The rate constant $k_{\mathrm{OH}}$ (water) $=k_{31}+k_{32}+k_{33}=k_{3}$ has to be determined for the chemical RH. The Eqs. (3.1) to (3.3) represent different reaction possibilities for $\mathrm{RH} . k_{\mathrm{OH}}$ (water) is determined from the slope of a plot of $R$ versus $2 r(1-R)$ according to

$$
\begin{aligned}
& R=2 \operatorname{ar}(1-R)+b ; \\
& R=\frac{\left[\mathrm{Fe}^{++}\right]}{2\left[\mathrm{H}_{2} \mathrm{O}_{2}\right]}, \quad r=\frac{\left[\mathrm{Fe}^{++}\right]_{0}}{2[\mathrm{RH}]_{0}}, \\
& a=\frac{k_{2}}{k_{31}+k_{32}+k_{33}}=\frac{k_{2}}{k_{3}}, \\
& b=\frac{k_{32}+2 k_{33}}{2\left(k_{31}+k_{32}+k_{33}\right)} .
\end{aligned}
$$

The slope $a$ should be determined using at least 3 or 4 different values of $r$ (ratio of the initial concentrations of $\mathrm{Fe}(\mathrm{II})$ and $\mathrm{RH})$. The intercept $b$ shows the relative importance of the reactions (3.2) and (3.3). If oxidation of the primarily produced alkyl radicals is the main process, the rate constants $k_{32}$ and $k_{3}$ become equal to zero and the observed intercept $b$ becomes zero, too. $k_{\mathrm{OH}}$ (water $)=k_{3}$ is determined from slope $a$, using the known rate constant $k_{2}$.

Possible side reactions like

$$
\begin{aligned}
& \cdot \mathrm{OH}+\mathrm{H}_{2} \mathrm{O}_{2} \rightarrow \mathrm{H}_{2} \mathrm{O}+\mathrm{HO}_{2} ; \quad k=(1.2-4.5) \cdot 10^{7} \\
& \mathrm{M}^{-1} \mathrm{~s}^{-1} \text {; } \\
& 2 \cdot \mathrm{OH} \quad \rightarrow \mathrm{H}_{2} \mathrm{O}_{2} ; \quad k=5.3 \cdot 10^{9} \mathrm{M}^{-1} \mathrm{~s}^{-1}
\end{aligned}
$$

are eliminated by suitable reaction conditions (see Experimental).

\subsubsection{Experimental (Wallings' Method)}

Reagents: $\mathrm{Fe}\left(\mathrm{ClO}_{4}\right)_{2} \times 6 \mathrm{H}_{2} \mathrm{O}$ purchased from Ventron, Karlsruhe. Purity and concentration were checked by AAS. The crystals contained additional water but only traces of $\mathrm{Fe}(\mathrm{III}) .5 \cdot 10^{-2} \mathrm{M}$ solutions in $0.1 \mathrm{M} \mathrm{HClO}_{4}$ were used. $\mathrm{HClO}_{4}$ and $\mathrm{H}_{2} \mathrm{O}_{2}$ (p.a. grade) were used. The grades of the other chemicals were Ökanal, p.a. or nanograde. All experiments were performed in an inert $\mathrm{N}_{2}$ atmosphere.

Performance of the test: The chemical for which the $k_{\mathrm{OH}}$ rate constant has to be determined is dissolved in such an amount of $0.1 \mathrm{M} \mathrm{HClO}_{4}$ that a volume of $60 \mathrm{ml}$ is obtained after addition of the $\mathrm{H}_{2} \mathrm{O}_{2}$ solution. The reaction vessel is thermostated at $30{ }^{\circ} \mathrm{C}$ and flushed with $\mathrm{N}_{2}$. The $\mathrm{H}_{2} \mathrm{O}_{2}$ solution is slowly added from a burette. To evaluate the kinetic parameters, the concentrations of $\mathrm{Fe}$ and $\mathrm{H}_{2} \mathrm{O}_{2}$ have to be determined when the reaction is finished.

The concentration of $\mathrm{Fe}$ ions can be measured photometrically: $\mathrm{Fe}$ (III) by the absorption of its thiocyanate complex, $\mathrm{Fe}$ (II) by its 1,10-phenanthrolin complex. The concentration of $\mathrm{H}_{2} \mathrm{O}_{2}$ is determined by titration with $\mathrm{KMnO}_{4}$.

\subsection{Determination of $k_{\mathrm{OH}}$ Rate Constants in F 113}

\subsubsection{Measuring Principle}

The $k_{\mathrm{OH}}$ rate constants of chemicals which are not soluble in water have to be measured in a nonpolar solvent. This solvent has to be capable of dissolving the chemical and $\mathrm{H}_{2} \mathrm{O}_{2}$, so that photochemical generation of $\mathrm{OH}$ radicals and their reaction with the chemical is possible. Furthermore, the solvent has to be inert toward $\mathrm{OH}$ radicals and must not react with any of the intermediate radicals, e.g. those created by abstracting $\mathrm{H}$-atoms from the test substance $\left(\mathrm{Rh}+\cdot \mathrm{OH} \rightarrow \mathrm{R}^{\cdot}+\mathrm{H}_{2} \mathrm{O}\right)$. After testing, several chloro- and fluoroalkanes, F 113 (1,1,2-trichloro-1,2,2-trifluoro ethane) turned out to be sufficiently stable. This corresponds to the result of Katz et al., who found that alkyl radicals cannot abstract halogen atoms from Freon 113 but are capable of abstracting chlorine from tetrachloromethane [27].

For the solvent F 113, no correlation between $k_{\mathrm{OH}}$ (air) and $k_{\mathrm{OH}}(\mathrm{F} 113)$ can be established since no $k_{\mathrm{OH}}$ rate constants have been measured in this solvent. Therefore it is necessary first to test wether $k_{\mathrm{OH}}$ rate constants in $\mathrm{F} 113$ are proportional to the rate constants in air. These experiments are described in Section 3.2.

In principle, $\mathrm{OH}$ radicals are created photochemically at wavelengths $>300 \mathrm{~nm}$,

$$
\mathrm{H}_{2} \mathrm{O}_{2} \stackrel{h v}{\longrightarrow} 2 \cdot \mathrm{OH} ; \text { rate: } k_{1}\left[\mathrm{H}_{2} \mathrm{O}_{2}\right],
$$

using $\mathrm{H}_{2} \mathrm{O}_{2}$ as the radical source. The solubility of $\mathrm{H}_{2} \mathrm{O}_{2}$ in $\mathrm{F} 113$ is $1.5 \cdot 10^{-3} \mathrm{M}$ if the equilibrium is established with $30 \%$ aqueous solution of $\mathrm{H}_{2} \mathrm{O}_{2}$. The $\mathrm{OH}$ radicals created are consumed by the test substance added in different concentration,

$$
\cdot \mathrm{OH}+\mathrm{RH} \stackrel{k_{\mathrm{OH}}}{\rightarrow} \text { Prod.; rate: } k_{\mathrm{OH}}[\mathrm{OH}][\mathrm{RH}],
$$

and by side reactions (e.g. $\cdot \mathrm{OH}+\mathrm{H}_{2} \mathrm{O}_{2} \rightarrow \mathrm{H}_{2} \mathrm{O}$ $+\cdot \mathrm{OOH})$ combined in the equation

$$
\cdot \mathrm{OH}+\mathrm{X} \stackrel{k_{\mathrm{x}}^{\prime}}{\rightarrow} \text { Prod.; rate: } k_{\mathrm{X}}[\mathrm{OH}] \text {. }
$$




\subsubsection{Experimental (Test in F 113)}

An aqueous solution of $\mathrm{H}_{2} \mathrm{O}_{2}(30 \%)$ and $\mathrm{F} 113$ were shaken to prepare a solution of $\mathrm{H}_{2} \mathrm{O}_{2}$ in $\mathrm{F} 113$. The maximum concentration of $\mathrm{H}_{2} \mathrm{O}_{2}$ in $\mathrm{F} 113$ is $1.5 \cdot 10^{-3} \mathrm{M}$. The concentration of $\mathrm{H}_{2} \mathrm{O}_{2}$ was determined by the absorption of the $\operatorname{Ti}$ (IV) $\mathrm{H}_{2} \mathrm{O}_{2}$ complex at $419 \mathrm{~nm} .1 \mathrm{ml}$ of $\mathrm{F} 113$ containing $\mathrm{H}_{2} \mathrm{O}_{2}$ was mixed with $5 \mathrm{ml}$ of acetic acid $(100 \%)$. After the addition of $1 \mathrm{ml}$ of the Ti(IV) solution (Merck Titrisol; $1 \mathrm{~g} \mathrm{Ti}(\mathrm{IV}) \mathrm{1}^{-1}$ in diluted $\mathrm{HCl}$ ) the volume was adjusted to $10 \mathrm{ml}$ with acetic acid. The con-

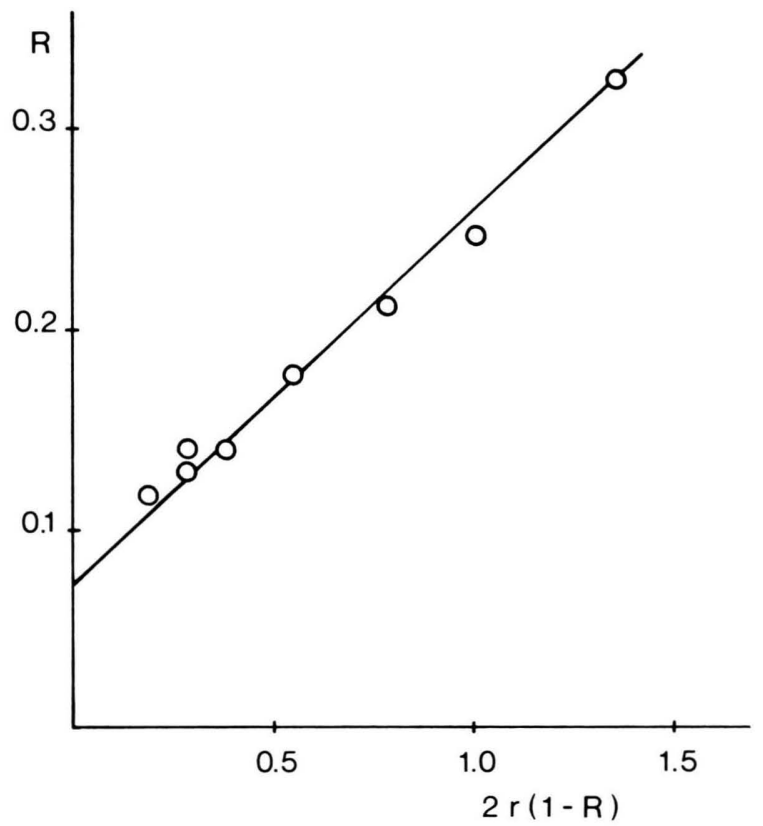

Fig. 2. Plot of $R$ versus $2 r(1-R)$. Substance: isopropanol. centrations of the various substances in F 113 were determined by gas chromatography. The experiments were conducted in a photochemical apparatus. For the generation of the OH-radicals the solutions were irradiated with UV-light $(\lambda \gtrsim 290 \mathrm{~nm})$. A high pressure mercury lamp TQ from Heraeus was used for the irradiation. All experiments were conducted under an inert nitrogen atmosphere.

\section{Results}

\subsection{Walling's Method}

The results of the measurements using 7 test substances are summarised in Table 2. Figure 2 shows a typical plot of $R$ versus $2 r(1-R)$ used for evaluation according to (7).

For ethylacetate, the measured $k_{\mathrm{OH}}$ (water) is considerably higher than data reported previously [9]. This may be due to difficulties encountered in measuring substances which are volatile from aqueous solution.

Urea reacts very slowly with $\mathrm{OH}$ radicals [20]. The evaluation of data according to (7) is not possible in this case, since most values of $R$ fall in the range 0.9 to 1.0 , so that the $(1-R)$ correction is subject to serious errors. A simplified plot of $1 / R$ vs. $1 / 2 r$ can be tried in these cases [4], which is strictly valid only if $k_{3}=k_{31}$. In the case of urea, the lower limit of the range of applicability of Walling's method is clearly reached. Correspondingly, the estimate of $k_{\mathrm{OH}}$ (air) is a very rough one.

Isopropanol, which had been investigated by Walling and Kato [13] behaves good-natured in water as well as with regard to extrapolation to the gas phase.

Table 2. Measured and estimated $k_{\mathrm{OH}}$ rate constants.

\begin{tabular}{|c|c|c|c|c|c|c|}
\hline \multirow[t]{2}{*}{ Substance } & \multicolumn{2}{|c|}{$k_{\mathrm{OH}}$ (water) $\left[\mathrm{M}^{-1} \mathrm{~s}^{-1}\right]$} & \multirow[t]{2}{*}{ Ref. } & \multicolumn{2}{|c|}{$k_{\mathrm{OH}}($ air $)\left[\mathrm{mol} . \mathrm{cm}^{-3} \mathrm{~s}^{-1}\right]$} & \multirow[t]{2}{*}{ Ref. } \\
\hline & $\begin{array}{l}\text { Measured } \\
\text { (this work) }\end{array}$ & Literature & & Estimated $^{\mathrm{a}}$ & Literature & \\
\hline Ethylacetate & $1.22 \cdot 10^{9}$ & $2.4-4.0 \cdot 10^{8}$ & [9] & $4.0 \cdot 10^{-12}$ & $1.0 \cdot 10^{-12}$ & [15] \\
\hline $\begin{array}{l}\text { Urea } \\
\text { Isopropanol }\end{array}$ & $\begin{array}{ll}2.1 & \cdot 10^{6} \\
1.6 & \cdot 19^{9}\end{array}$ & $\begin{array}{r}<1.25 \cdot 10^{6} \\
2.0 \cdot 10^{9}\end{array}$ & $\begin{array}{l}{[14]} \\
{[13,9]}\end{array}$ & $\begin{array}{l}1.4 \cdot 10^{-14} \\
5.1 \cdot 10^{-12}\end{array}$ & $5.48 \cdot 10^{-12}$ & [15] \\
\hline Methanol & $1.23 \cdot 10^{9}$ & $0.85 \cdot 10^{9}$ & [9] & $4.1 \cdot 10^{-12}$ & $1.0 \cdot 10^{-12}$ & {$[15]$} \\
\hline Dichloromethane & $2.2 \cdot 10^{7}$ & - & & $1.1 \cdot 10^{-13}$ & $1.5 \cdot 10^{-13}$ & [15] \\
\hline p-Nitrophenol & $3 \cdot 10^{9}$ & $3.8 \cdot 10^{9}$ & [11] & $9 \cdot 10^{-1}$ & & \\
\hline Phenol & $>3 \cdot 10^{9}$ & $1.4 \cdot 10^{10}$ & [9] & $3.5 \cdot 10^{11}$ & $2.8 \cdot 10^{-11}$ & [1] \\
\hline
\end{tabular}

\footnotetext{
a according to $\log k_{\mathrm{OH}}$ (air) $=1.29+0.891 k_{\mathrm{OH}}$ (water) [7, 8] from data obtained in this work except for phenol.
} 
Methanol is kinetically simple since only one $\mathrm{C}$-radical can be formed $\left(\mathrm{CH}_{3} \mathrm{OH}+\cdot \mathrm{OH} \rightarrow \mathrm{H}_{2} \mathrm{O}\right.$ $+\cdot \mathrm{CH}_{2} \mathrm{OH}$ ); the alcoholic $\mathrm{H}$ is more strongly bound and practically does not react. A plot according to (7) yields $b=0$, i.e. $k_{32}=k_{33}=0$.

Dichloromethane is volatile and slowly reacting; the evaluation can be done, as in the case of urea, only using the simplified plot. The coincidence with gas phase literature data is good.

High reactivity toward $\mathrm{OH}$ is indicated by p-nitro phenol; the coincidence with $k_{\mathrm{OH}}$ (water) data is satisfactory. No gas phase data are available for comparison with the extrapolated value. Only the lower limit of $k_{\mathrm{OH}}$ (water) could be established for phenol $\left(a \approx 0 ; k_{3} \gg k_{2}\right)$. The extrapolation of literature data of $k_{\mathrm{OH}}$ (water) is in very good agreement with $k_{\mathrm{OH}}$ (air).

\subsection{Hydrogen Peroxide in F 113}

The reaction of photolytically generated $\mathrm{OH}$ radicals in $\mathrm{F} 113$ has been studied with four substances of widely different OH-reactivity, as measured in the gas phase $\left(k_{\mathrm{OH}}\right.$ given in parentheses, $\left.\mathrm{M}^{-1} \mathrm{~s}^{-1}\right)$ : limonene $\left(8.4 \cdot 10^{10}[7]\right)$, phenol $\left(1.7 \cdot 10^{10}[1]\right)$, toluene $\left(3.7 \cdot 10^{9}[1,15]\right)$ and $1,2,4$-trichlorobenzene $\left(3.8 \cdot 10^{8}[7]\right)$.

The initial concentrations $[\mathrm{RH}]_{0}$ of the test substances were $10^{-4}$ to $10^{-3} \mathrm{M}$ for limonene, toluene and 1,2,4-trichlorobenzene, and $10^{-5}$ to $10^{-4} \mathrm{M}$ for phenole. The initial concentration of hydrogen peroxide $\left[\mathrm{H}_{2} \mathrm{O}_{2}\right]$ was approximately $1.5 \cdot 10^{-3} \mathrm{M}$. The experiments showed that the testsubstances disappeared exponentially as a function of irradiation time, indicating an approximately stationary concentration of $\mathrm{OH}$ radicals:

$$
\ln [\mathrm{RH}]=\ln [\mathrm{RH}]_{0}-k_{\mathrm{OH}}[\mathrm{OH}] t .
$$

Evidently, $k_{\mathrm{OH}}[\mathrm{OH}]$ can be determined from the slope of semilogarithmic plots according to (11). The concentration of $\mathrm{OH}$ radicals can only be estimated, using the gas phase reaction constants. The $\mathrm{OH}$ concentrations in $\mathrm{F} 113$ estimated in this way range from $10^{-16}$ to $10^{-14} \mathrm{M}$.

Assuming stationary conditions, the equation

$$
\frac{1}{[\mathrm{OH}]}=\frac{k_{\mathrm{OH}}[\mathrm{RH}]}{k_{1}\left[\mathrm{H}_{2} \mathrm{O}_{2}\right]}+\frac{k_{\mathrm{X}}}{k_{1}\left[\mathrm{H}_{2} \mathrm{O}_{2}\right]}
$$

is derived from (8) to (11).
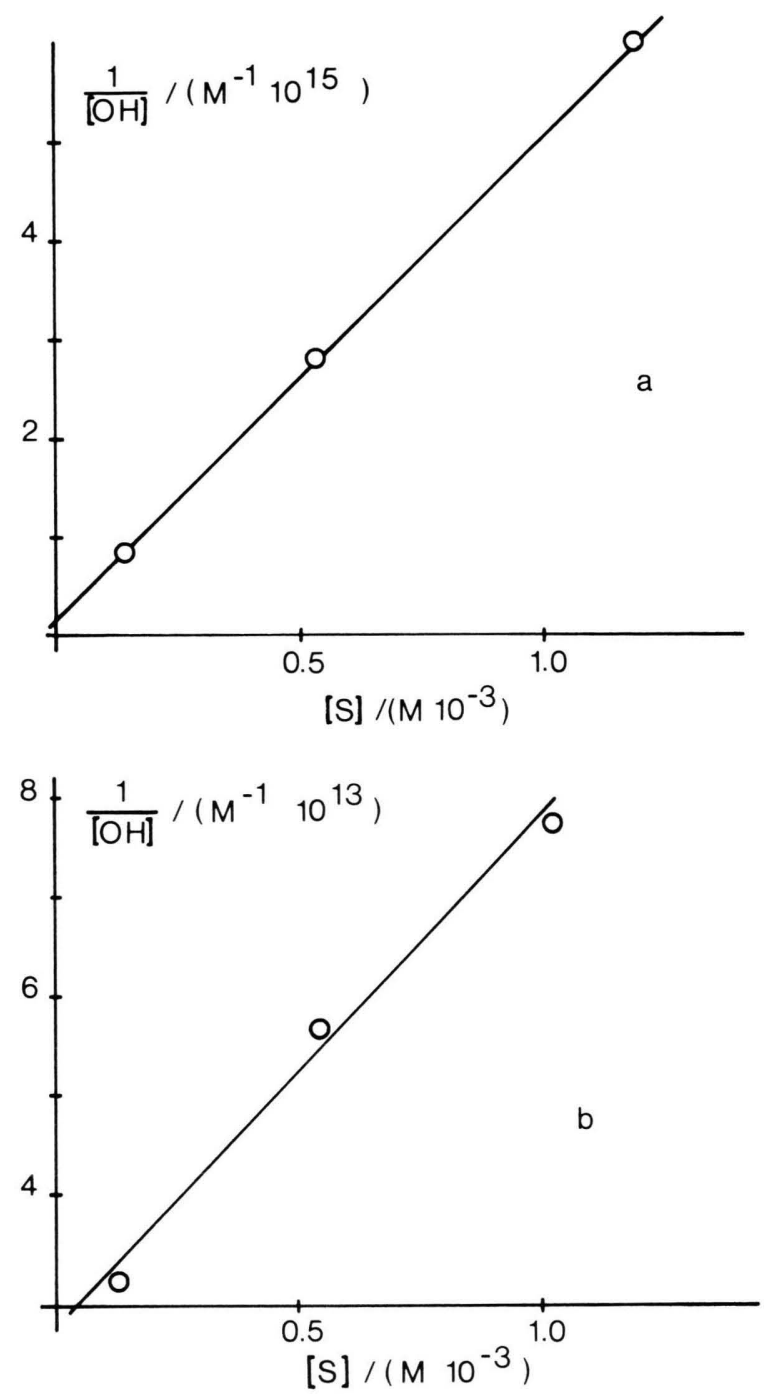

Fig. 3. Plots of $1 /[\mathrm{OH}]$ versus initial concentration of $\mathrm{RH}$. a) Limonene, b) 1,2,4-trichlorobenzene.

According to (12) a linear correlation should exist between $1 /[\mathrm{OH}]$ and $[\mathrm{RH}]$. Using the estimated $[\mathrm{OH}]$ values, $1 /[\mathrm{OH}]$ can be plotted versus the initial concentrations of the substances $[\mathrm{RH}]_{0}$. All plots yield straight lines (Figure 3). Equation (12) can also be used to test whether the rate constants in Freon 113 are proportional to the $k_{\mathrm{OH}}$ (air) rate constants plotting $1 /[\mathrm{OH}]$ versus $k_{\mathrm{OH}}$ (air). The values of $1 /[\mathrm{OH}]$ have to be determined for equal concentrations of $\mathrm{RH}$ and $\mathrm{H}_{2} \mathrm{O}_{2}$ and with equal irradiation intensity. Figure 4 shows the plot obtained. The data points lie on a straight line. Although further chemicals have to be measured in 


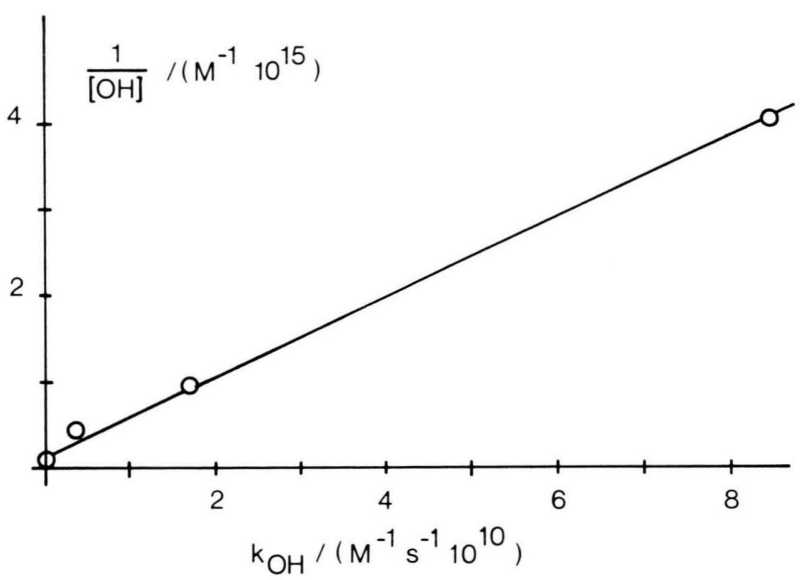

Fig. 4. Plot of $1 /[\mathrm{OH}]$ versus $k_{\mathrm{OH}}$ (air).

order to test the reliability of the method, it appears that $k_{\mathrm{OH}}$ rate constants between $4 \cdot 10^{8}$ and $8.5 \cdot 10^{10}$ $\mathrm{M}^{-1} \mathrm{~s}^{-1}$ will be measurable.

\section{Discussion}

The main advantage of Walling's method is its simplicity, only conventional laboratory equipment being required so that the test can be performed in any laboratory. The correlations between the values measured in water and extrapolated to the gas phase and the values measured in the gas phase is sufficiently exact for the estimation of tropospheric lifetimes. The optimum range for determining rate constants $k_{\mathrm{OH}}$ (water) is between $3 \cdot 10^{7}$ and $3 \cdot 10^{9}$ $\mathrm{M}^{-1} \mathrm{~s}^{-1}$. The upper limit is due to diffusion control. Extrapolation to the gas phase of that region corresponds to rate constants between $5 \cdot 10^{-14}$ and $5 \cdot 10^{-12} \mathrm{~cm}^{3} \mathrm{~mol}^{-1} \mathrm{~s}^{-1}$. The rate constants of many air pollutants are situated in this region.

The use of Walling's method is limited by several constraints which determine the number of substances which can be tested. (i) The water solubility of the substances under concern should exceed $10 \mathrm{~g} \mathrm{dm}^{-3}$. (ii) The $\mathrm{pH}$ of the test solution is very low so that bases and salts of weak acids will be protonated in contrast to ordinary environmental conditions. (iii) The substances should not form strong complexes with $\mathrm{Fe}(\mathrm{II})$ or $\mathrm{Fe}(\mathrm{III})$. (iv) $\mathrm{Co}-$ loured oxidation products may disturb the photomeric determination of concentration.

The measurement of volatile components still has to be improved.
In order to overcome these problems in the future, other simple methods for the production of $\mathrm{OH}$ radicals should be investigated additionally, e.g. photochemical generation from $\mathrm{H}_{2} \mathrm{O}_{2}$ (a similar method is already being applied in polarographic analysis for the destruction of disturbing organic chemicals). For the determination of $k_{\mathrm{OH}}$ rate constants, this procedure has to be combined with efficient analytical methods which allow the disappearance of the test chemicals to be measured relative to suitable reference substances.

The same is true for F 113 as an inert solvent for non-polar compounds. The first results presented here indicate that at least a ranking of different chemicals with regard to $\mathrm{OH}$-reactivity is possible. Relative rate constants $k_{\mathrm{OH}}(\mathrm{F} 113)$ can be determined as soon as at least one reliable absolute $k_{\mathrm{OH}}$ will have been measured in this solvent.

The suggested rapid test would be especially suited to investigate the environmental fate of less volatile substances $\left(P_{25}<10^{-2} \mathrm{~Pa}\right)$, e.g. DDT and other molecularly dispersed environmental chemicals. As it is not possible to measure the rate constants of these chemicals in the gas phase, the measurement should be performed in an inert solvent, or in more than one solvent preferably. Comparison of the results of the different experiments may then be used to evaluate $k_{\mathrm{OH}}$ rate constants which are good estimates of the exact values. Water and Freon 113 have been shown to be suitable solvents in this work.

For calculations of the atmospheric lifetime

$$
t_{1 / 2}=\ln 2 /\left(k_{\mathrm{OH}}(\text { air) }[\mathrm{OH}]),\right.
$$

$\mathrm{OH}$ radical concentrations of approximately $5 \cdot 10^{5}$ to $10^{6} \mathrm{~mol} . \mathrm{cm}^{-3}$ are used.

If (13) is used for estimating the atmospheric lifetime, it is assumed that the reaction with $\mathrm{OH}$ radicals is the most efficient sink of the chemical. The actual tropospheric residence time may be much shorter due to wash out, dry deposition and other transfer processes.

The measurement of tropospheric $\mathrm{OH}$ radical concentrations is still a problem; values between $10^{5}$ and $10^{7} \mathrm{~mol} . / \mathrm{cm}^{3}$ have been reported $[1,21-25]$. For a preliminary estimate of a chemical's tropospheric lifetime, approximate $k_{\mathrm{OH}}$ values are sufficiently correct. The suggested rapid test is therefore especially useful to fulfil the demands of chemicals legislation (abiotic degradation) in its low tiers. 


\section{Acknowledgement}

This work was sponsored by the Bundesministerium für Forschung und Technologie, Projektträgerschaft Umweltchemikalien (KFA Jülich). The support is greatfully acknowledged. One of us (W.K.)

[1] K. H. Becker, H. M. Biehl, P. Bruckmann, E. H. Fink, F. Führ, W. Klöpffer, R. Zellner, and C. Zetzsch (Hrsg.), Methods of the Ecotoxicological Evaluation of Chemicals. Photochemical Degradation in the Gas Phase. Vol. 6: $\mathrm{OH}$ Reaction Rate constants and Tropospheric Lifetimes of Selected Environmental Chemicals. Report 1980-1983. Kernforschungsanlage Jülich $\mathrm{GmbH}$, Projektträgerschaft Umweltchemikalien. Jül-Spez-279, 1984, ISSN 0343-7639.

D. L. Baulch, R. A. Cox, P. J. Crutzen, R. F. Hampson Jr., J. A. Kerr, J. Troe, and R. T. Watson, J. Phys. Chem. Ref. Data 11, 327 (1982).

[2] W. Cautreels and K. van Couwenberghe, Atmos. Environ. 12, 1133 (1978).

[3] C. Springer, L. J. Thibodeaux, and C. Shrikrishna, Simulation Study of the Volatilization of Polychlorinated Biphenyls from Landfill Disposal Sites, p. 209. In: W. C. Francis and S. I. Auerbach (eds.), Environment and Solid Wastes, Butterworth, Boston, London 1983.

[4] C. Walling, Acc. Chem. Res. 8, 125 (1975).

[5] W. Klöpffer, Rapid Test for Simulation of Photooxidative Degradation in the Gas Phase. In: Proceedings of an International Workshop on Test Methods and Assessment Procedure for the Determination of the Photochemical Degradation Behaviour of Chemical Substances. Berlin, December 1980, p. 194.

[6] H. Güsten, W. G. Filby, and S. Schoof, Atmos. Environm. 9, 1763 (1981).

[7] R. Frank, G. Kaufmann, and W. Klöpffer, Prüfverfahren zur raschen Abschätzung der Geschwindigkeit des photochemisch-oxidativen Abbaus von Chemikalien in der Atmosphäre. Report BMFT PTU 037296.

[8] R. Frank, G. Kaufmann, and W. Klöpffer, Phototransformation of Air Pollutants: Rapid Test for Estimating k-OH Rate Constants. Proceedings of the $\mathrm{X}$ th IUPAC Symposium on Photochemistry. July 1984 , p. 403.

[9] L. M. Dorfmann and G. E. Adams, Reactivity of the hydroxylradical and aqueous solutions. Rep. NSRDSNBS 46 Nat. Bureau of Standards, Washington 1973.

[10] A. Wigger, W. Grünbein, H. Henglein, and E. G. Land, Z. Naturforsch. 24 b, 1262 (1969).

[11] Farhataziz, A. B. Ross, Selected specific rates of reactions of transients from water in aqueous solution. thanks Prof. Walling for a discussion during the EUCHEM Conference on Organic Radicals at Elmau 1983.

We especially thank Professor Warneck, for drawing our attention to Walling's method.

III. Hydroxylradical and perhydroxylradical and their radical ions. Rep. NSRDS-NBS 59 Natl. Bur. of Standards Washington D.C. (1977).

[12] K. Selested, H. Corfitzen, H. J. Christensen, and E. J. Hart, J. Phys. Chem. 79, 310 (1975).

[13] C. Walling and S. Kato, J. Amer. Chem. Soc. 93, 4275 (1971).

[14] M. Anbar and P. Neta, Int. J. Appl. Rad. Isotopes 18, 493 (1967)

[15] R. Atkinson, K. R. Darnell, A. C. Lloyd, A. M. Winer, and J. N. Pitts, Jr., Advances in Photochemistry, Vol. 11, Wiley, New York 1979, p. 375.

[16] P. Marathamuthu, Macromol. Chem. Rap. Commun. $1,23(1980)$.

[17] J. A. Kerr and D. W. Sheppard, Environ. Sci. Technol. 15, 960 (1981).

[18] R. Atkinson, S. M. Aschmann, A. M. Winer, and J. N. Pitts, Jr., Int. J. Chem. Kinet. 14, 507 (1982).

[19] T. E. Graedel and C. J. Weschler, Rev. Geophys. Space Phys. 19, 505 (1981).

[20] I. Kraljic and C. N. Trumbore, J. Amer. Chem. Soc. 87, 2547 (1965).

[21] G. Ortgies and F. Comes, Appl. Phys. B 33, 103 (1984).

[22] R. Zeller and J. Hägele, in: Optical methods for the remote sensing of air pollution, Ed.: S. Sandroni, Elsevier, Amsterdam 1984, p. 351.

[23] D. Perner, D. H. Ehhalt, H. W. Pätz, U. Platt, E. P. Röth, and A. Volz, Geophys. Res. Lett. 3, 466 (1976).

[24] C. C. Wang, L. I. Davis, Jr., P. M. Selzer, and R. Munez, J. Geophys. Res. 86, 1181 (1981).

[25] T. Watanabe, K. Abe, Y. Massayuki, F. Shizuo, O. Atsushi, H. Minoru, and I. Shunji, Anal. Chem. 54, 2470 (1982).

[26] W. L. Chameides and D. D. Davis, J. Geophys. Res. 87, $4863(1982)$

[27] M. G. Katz, G. Baruck, and L. A. Rajbenbach, Int. J. Chem. Kinet. 8, 599 (1976).

[28] O. J. Nielsen, P. Pagsberg, and A. Sillesen, Kinetics of the Reaction of $\mathrm{OH}$ with Ethane and a Series of $\mathrm{Cl}-$ and F-substituted Methanes at 300-400 K. Proceedings of the Third European Symposium on Physicochemical Behaviour of Atmospheric Pollutants. Varese (Italy) April 10-12 (1984). 